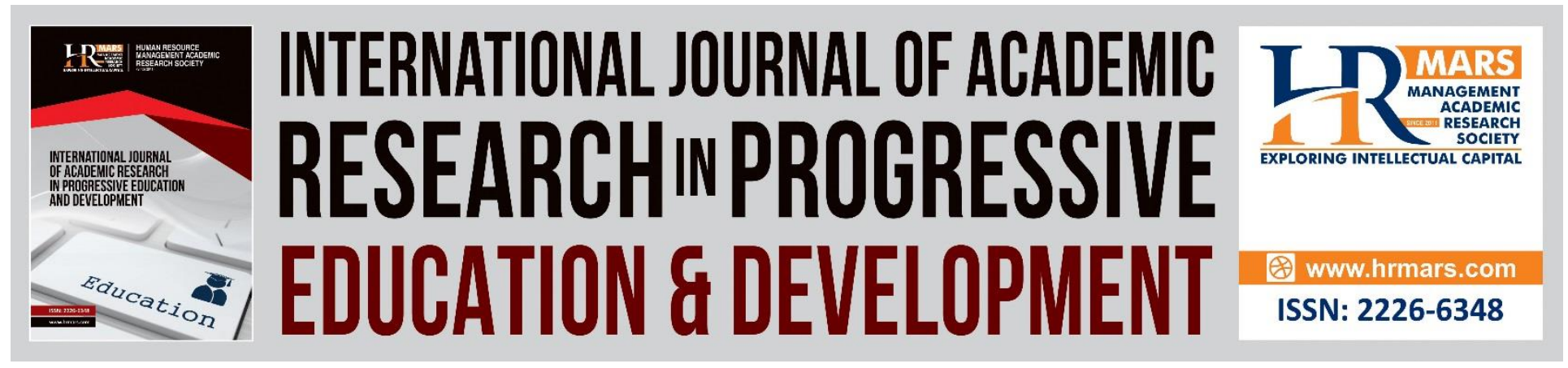

\title{
Assessing Perlocutionary Effects through Directive Speech Acts in an Autistic Child during Joint Comprehension Activities
}

Muhammad Nazrin Rosli, Afida Mohamad Ali, Ain Nadzimah Abdullah, Hamidin bin Awang, Shameem Rafik-Galea

To Link this Article: http://dx.doi.org/10.6007/IJARPED/v10-i1/8384

DOI:10.6007/IJARPED/v10-i1/8384

Received: 04 January 2021, Revised: 31 January 2021, Accepted: 19 February 2021

Published Online: 16 March 2021

In-Text Citation: (Rosli et al., 2021)

To Cite this Article: Rosli, M. N., Ali, A. M., Abdullah, A. N., Awang, H. bin, \& Rafik-Galea, S. (2021). Assessing Perlocutionary Effects through Directive Speech Acts in an Autistic Child during Joint Comprehension Activities. International Journal of Academic Research in Progressive Education and Development, 10(1), 248267.

Copyright: (C) 2021 The Author(s)

Published by Human Resource Management Academic Research Society (www.hrmars.com)

This article is published under the Creative Commons Attribution (CC BY 4.0) license. Anyone may reproduce, distribute, translate and create derivative works of this article (for both commercial and non-commercial purposes), subject to full attribution to the original publication and authors. The full terms of this license may be seen at: http://creativecommons.org/licences/by/4.0/legalcode

Vol. 10(1) 2021, Pg. 248 - 267

http://hrmars.com/index.php/pages/detail/IJARPED JOURNAL HOMEPAGE

Full Terms \& Conditions of access and use can be found at http://hrmars.com/index.php/pages/detail/publication-ethics 


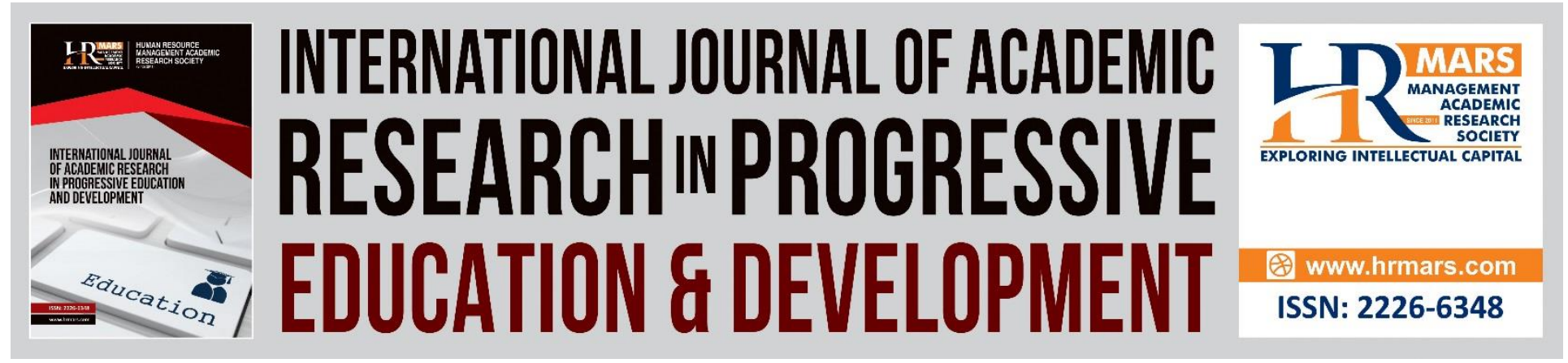

\title{
Assessing Perlocutionary Effects through Directive Speech Acts in an Autistic Child during Joint Comprehension Activities
}

\author{
Muhammad Nazrin Rosli, Afida Mohamad Ali, Ain Nadzimah \\ Abdullah, Hamidin bin Awang, Shameem Rafik-Galea \\ Universiti Putra Malaysia
}

\begin{abstract}
The study analysed the perlocutionary effects elicited by an autistic child through the use of directive speech acts during joint comprehension activities. While studies related to ASD are largely conducted quantitatively, this study incorporated a case study method involving a Malaysian English speaking ASD child, to analyse the conversational interactions between the subject and the interlocutor during joint comprehension activities. This case study draws on Searle's (1975) framework, under which the speech acts are described alongside perlocutionary actions which are analysed through discourse analysis. The data of the case study was collected through audio/video recordings, and triangulated with observations during the joint comprehension activities, as well as interviews with the parents and teacher. The definitions and classifications of the disorder were reviewed from the first description by Kanner (1943) and the Theory of Mind (Leslie, 1987) interpretation of the core impairments in Autism, to the current $5^{\text {th }}$ Diagnostic and Statistical Manual of Mental Disorders (DSM-V, 2013) classifications. Many patterns of communication arose from the use of the directive speech acts which impede and support interaction. Findings also revealed that specific communication skills used by the special needs facilitator have implications for communication in English where meaningful interactions can be formed with the Autistic child. This could help to create awareness among educators in designing special needs learning materials, especially in Malaysia.
\end{abstract}

Keywords: Autism, ASD, Speech Acts, Perlocutionary Effects, Directives.

\section{Introduction}

Autism spectrum disorder is a neurodevelopmental disorder with a biological basis, which usually manifests in the first three years of life. Children diagnosed with Autistic Spectrum Disorder (ASD) are different from their 'typical developing' (TD) peers in many ways (Shire et al., 2020), especially in regards to social abilities. A known guideline to the difference would be that the ASD children possess features known as the Triad of Impairments (Tol) (Wing, 1981). Triad of Impairments refers to the three core deficits found in ASD children, namely, in socialization and social interaction, language and communication, and a preference for repetitive, stereotyped 
behaviour rather than creative play (Faras, 2010; Hie \& Kee, 2019). This triad is the crux of autism and is evident even in those with a very high level of cognitive ability, therefore requiring acknowledgment on the part of the supervisor and the parents (Liao et al., 2019), during interaction with the child (Wire, 2005. p. 2).

The conditions on the spectrum broadly differ in terms of the severity of symptoms. Autism is a developmental disorder, affecting more than six children in a thousand, and second only in frequency to mental retardation (Newschaffer et al., 2007. p. 1). It is a life-long biological disorder with a wide range of appearances. As the autistic diagnosis includes individuals of very different aptitudes in different criteria, autism refers to Autism Spectrum Disorders (ASD) (Frith \& Happé, 1994). Allott (2001) stated that the underlying condition of autism has been untreatable through many different forms of treatment with limited success so far. In addition, there is presently no consensus about the fundamental causes of autism.

For a better understanding of the disorder, it is essential to explain DSM-V, which is the standard classification of mental disorders and includes the current diagnosis of an ASD individual. DSM-V (5th Diagnostic and Statistical Manual of mental disorders) published by the American Psychiatric Association (2013), addresses four main characteristics in the diagnosis of an ASD child. Firstly, there are persistent deficits in social communication and social interaction across multiple contexts, such as social-emotional reciprocity where the ASD child would exhibit a lack of emotion in his/her responses (Shire et al., 2020), showing minimal empathy towards the speaker's situation, and exhibiting limited nonverbal communication such as gesturing and maintaining eye-contact. Secondly, restricted, repetitive patterns of behaviour, interests, or activities can be seen in the child. Thirdly, the symptoms must also be present in the early developmental period and cause clinically significant impairment in social, occupational, or other important areas of current functioning, such as not being able to cooperate in a classroom due to unusual social interactions. Finally, the symptoms mentioned should not be confused with an intellectual disability (intellectual developmental disorder) or global developmental delay such as Dyslexia. Unlike the dated versions of the DSM such as DSM 1 to four, the DSM-V categorizes the classes of the disorder into three levels of severity, namely, level 1 with the lowest severity up to level 3 with the highest severity (American Psychiatric Association, 2013). It is also worthy to note that the subject of the study is categorized under Level 1 of severity under the DSM-V. In line with this instrumental preference, children with autism are reported to produce more feedback during interaction and comprehend better towards directive speech acts than speech acts that facilitate shared understanding such as representatives and expressive speech acts (Baron-Cohen, 1985; 2019). Searle (1975) also argued that in order to understand indirect speech acts, the speaker and hearer need to have mutually shared factual background information, and the ability of the hearer to make inferences (Wahyunianto et al., 2020). Subsequently upon application, it is harder to apply to interactions with the children with ASD due to the pragmatic deficit that they share (Shire et al., 2020).

This study aims to investigate Talk-In-Interaction of a Malaysian Autistic (ASD) child whose L1 is English, during joint comprehension activities. Thus, the specific objective of this study is to examine the perlocutionary effects in the conversational structure of the ASD child, through directive speech acts by the interlocutor. In retrospect, the findings of the study are expected to 
Vol. 10, No. 1, 2021, E-ISSN: 2226-6348 @ 2021 HRMARS

reveal how the use of directive speech acts affect the interaction with the ASD child in terms of the perlocutionary effects during joint comprehension activities.

\section{Literature Review}

Studies on ASD in Malaysia have primarily focused on strategies and interventions for language and cognitive development (Yeo \& Teng, 2015) where the recorded data in the class or laboratory setting are not analyzed using discourse analytic approaches. These studies have not looked at the patterns and features of language impairments produced by ASD children that are used throughout the different aspects in conversation such as socio-pragmatic functions, speech acts, organization of turn-taking, sequences and organization of repair in perlocutionary feedback, and strategies in avoiding feedback. An exception can be seen in Che An's (2010) work on the sociopragmatic functions in the speech interactions of an ASD teenager.

Studies on ASD outside of Malaysia predominantly in the western hemisphere has looked into many differing perspectives, with one that is in line with this study, would be those grounded in conversational and discourse analytic measures. Through conversation and discourse analysis, this perspective looks into atypical language features, social and collaborative group processes, subject's orientation to social rules, discourse in narrative introduction, impairment in emotion expression, and meaning-making (Watkins et al., 2015; Hochman et al., 2015; O'Reilly et al., 2016). The availability of analyzing discourse findings on a moment-to-moment basis through conversational or discourse analysis enables specific criteria to be studied (Sterponi \& de Kirby, 2016) such as the effects of language atypicality in the discourse. The study by Wahyunianto, Djatmika and Dwi (2020), looks at the use of speech acts as a communication strategy with Autistic children. The results surprisingly showed that most of the children with autism were using a directive speech act. The other type of speech acts employed by the children was assertive, which could correlate with the findings of this current study.

Pragmatic knowledge refers to how individuals communicate meaning and how they produce contextually appropriate utterances, sentences, or texts. Examples of pragmatic knowledge include sociolinguistic and functional knowledge (Kasher, 1991). Deficit of pragmatic knowledge in ASD children is in-line with their lacking Theory of Mind (ToM) (Hobson, 2019), where the ASD children are not able to comprehend the pragmatic aspects during a conversation namely; the usage of implicatures to convey a specific message (Baron-Cohen, 1988). The theory states that autistic children have a specific problem with mental representations and do not develop the ability to mind-read or rather, to comprehend the intentions of the speaker

This study is grounded in Speech Act Theory since it investigates how the subject demonstrates the use of speech acts as well as the perlocutionary reaction towards certain speech acts. Speech act theory was first developed by Austin (1962), who proposed a three-fold classification of utterances: locutionary acts, illocutionary acts, and perlocutionary acts. Locution is the actual words that are uttered, illocution refers to the force that makes it a particular act, and perlocution is the effect of the illocution on the hearer to carry out the particular act. In line with this theory, children with autism are reported to produce more feedback during interaction and comprehend 
better towards directive speech acts than indirect speech acts that facilitate shared understanding such as representatives and expressive speech acts (Baron-Cohen, 1985; 2019). Searle (1975) also argued that in order to understand indirect speech acts, the speaker and hearer need to have mutually shared factual background information, and the ability of the hearer to make inferences. Searle made a distinction between direct and indirect speech acts. Indirect speech acts being utterances that are understood from the context without mentioning the act itself (Searle, 1979).

The interest of the study also arose from personal observations at the selected school for special abilities as well as the child's home which revealed possible problems in interaction and the use of appropriate communication skills during joint comprehension activities. (Adamson et al., 2019) Apart from the lack of studies using conversation or discourse analytic approaches ( $O^{\prime}$ 'Reilly et al., 2016) and the wide gap of knowledge mentioned, another factor that may have not been focussed before is that although the ASD child is of Malay descent, his first language is English (based on personal communication with a medical specialist,). Human ancestry correlates with language (Baker et al., 2017), though such a phenomenon where Malaysian children having English as their first language is becoming less unusual due to the country's realization of the importance of the English language, it would be interesting to consider such variable.

In regards to DSM-V (5th Diagnostic and Statistical Manual of Mental Disorder), Malaysian studies on ASD children do not categorize their ASD subjects according to the severity of ASD although the DSM-V states that there are different levels of severity. Children who are classed at Level 1 'require support'; children that are classed at Level 2 'require substantial support', while children that are classed at Level 3 'require very substantial support (American Psychiatric Association, 2013). Not classifying or categorizing ASD subjects according to levels of severity in studies involving ASD children may limit the understanding of how different levels of severity impedes pragmatic knowledge that they are facing during interactions. As the subject is categorised at level 2 (based on diagnosis by a medical specialist,) in terms of his severity in the spectrum, the interactions between him and the facilitator does indeed show a consistent effort of prompting so that they are continuous. A different set of prompts may be needed with another possible subject with different severity in the spectrum.

The gaps of knowledge mentioned above present little contribution towards the overall state of awareness regarding the language development of Malaysian ASD children, thus, presenting a gap in understanding the interactions of a Malay child whose first language is English with a nonnative English background. Hence, the study addresses the following question:

How does the use of directive speech acts affect the interaction with the ASD child in terms of the perlocutionary effects during joint comprehension activities?

\section{Methodology}

The study utilizes a discourse analytic approach (Wibowo et al., 2020) in analysing the interaction activities with the interlocutor and focuses on the use of language and communication patterns 
of the ASD child. Methodologically, the analysis of the findings focuses on the type of communication patterns that occurs during the joint-comprehension activities as well as analysing the speech acts involved, the structure and sequence(s) of the interaction. The single case study method was used, and therefore, the findings cannot be generalized to a broader population or group of ASD children. Using a case study approach, the researcher was able to focus on specific cases such as the subject of the study rather than a statistical study. Not only is the study opinion-based, but a case study approach would enable the researcher to study complex phenomena within the participant's context. At the end of the study, the researcher would be able to develop theory(s) from the results, evaluate programs that were used, and may be able to develop interventions for the problem stated (Baxter \& Jack, 2008)

This research adapts an inductive approach where it explores a previously researched phenomenon from a different perspective (Thomas, 2006). This is done to open the way for more exploration of language elements that take place between the interlocutor and the ASD child. This is because through prior observations and past studies (Baron-Cohen et al., 1985; TagerFlusberg et al., 2015; Parsons et al., 2019), it was noted that ASD children are homogenous, where findings (verbal responses) often vary. Hence, data via video/audio recordings, observation, and field notes were compared against different taxonomies and frameworks proposed by different researchers in the field, namely; Baron-Cohen's Theory of Mind (1985); Searle's (1975) Speech Act Theory These taxonomies and frameworks are used to classify the types and pragmatic functions of the linguistic features and communication patterns utilized by the ASD child during an interaction. This is to ensure the authenticity of the findings, including making sure that there are no overlaps or contradictions. These patterns were interpreted linguistically against Searle's (1975) Speech Act Theory.

The participants of the study include the subject, the parents, and the teacher. The subject is a Malay 9-year old ASD child from Malaysia whose first language is English. The ASD child was chosen based on criterion sampling, and consent was granted by both the administration of the special needs school where the subject was enrolled in and the subject's parents. The parents and teacher(s) of the subject acted as the interlocutors and were interviewed on the subject's communication patterns and additional related information such as his behaviour and social skills at home and school. The parents conveyed their preference to have their familial details undisclosed in the study as parents of children with autism perceived and experienced stigma and various consequences which were varied with behaviors of autism and the severity of symptoms (Liao et al., 2019). Whereas the teachers were identified by their names without affiliation to the school itself. The participation of the subject is incremental and therefore, careful considerations were taken in the involvement of the subject. Before asking for consent from the parents of the subject, the study was carefully vetted by the supervisory committee as well as the University's Ethics Committee. Following ethical considerations through vetting and receiving the consent from the family members of the subject, the validity and reliability of the data were also taken into perspective. 
Vol. 10, No. 1, 2021, E-ISSN: $2226-6348$ @ 2021 HRMARS

The locations of the study consisted of the subject's home and the school that the subject is enrolled in. Due to ethical reasons, the name of the school is kept confidential. However, the school is listed in the Ministry of Education's website and is registered with the same Ministry.

Three methods were implemented to collect the data for the study, which consisted of interviews with the participants of the study, video recording of the joint comprehension activities, and field notes through guided observations of the said activities. Firstly, the parents were interviewed on the language development history of the subject. The interview is to gain the history and background knowledge of the participants. This is important as it is used as reference for the data analysis.

Next, joint comprehension activities were recorded. The interaction of the child and the interlocutor were audio-video recorded every two (2) weeks for three (3) months duration, with a total of six (6) recorded sessions. Each session of Joint-Comprehension Activity was around 30 to 45 minutes amounting to 3 to 6 hours of recording. Dibley (2011) stated that it may be best to think of data in terms of rich and thick rather than the size of the sample (Burmeister, \& Aitken, 2012). The data collected was recorded to a saturation point in which further similar observations by the researcher were rendered redundant and repetitive data (O'Reilly \& Parker, 2013). The recordings were transcribed and the observation notes taken during the recording of the data are used to supplement the analysis of the recording by way of personal reference and not utilized as data. Rubin and Rubin (2005) stated that "even when you are recording electronically, you should still take some notes" (p. 111).

A discourse analysis approach was used to identify the speech acts involved as well as the perlocutionary actions elicited by the child. The analysis involves the speech acts implemented, namely; directive speech acts, during interactions with the interlocutor. In order to answer the research question, Searle's (1975) framework was used for analysis. The outcome of implementing the directive speech acts by the interlocutor were analysed through perlocutionary effects exhibited by the subject. While the conversational structure and turn-taking sequence were taken into consideration, the perlocutionary effects could also include non-verbal responses. The field and observation notes provided more context on the perlocutionary action performed (Sparapani et al., 2020). An example of data analysis can be seen below.

According to Searle's Speech Act Theory (1975), speakers perform illocutionary acts to convey communicative intentions, such as requests, apologies, and promises. The subject was observed to work along with the interlocutor, and even reaffirms his understanding of directives by the interlocutor before performing a perlocutionary action. This can be seen in the following excerpt: 


\section{DEVELOPMENT}

Vol. 10, No. 1, 2021, E-ISSN: 2226-6348 @ 2021 HRMARS

Location: Subject's Home

Participants: Interlocutor (I), Subject (A).

\begin{tabular}{|l|l|l|}
\hline 27 & I & A look closely you will have to do this on your own later \\
\hline 28 & A & later, you have own. Cut your own pieces \\
\hline 29 & I & yes, \\
\hline 30 & A & $\ldots$...looks closer) \\
\hline
\end{tabular}

After reaffirming his understanding of the directive through paraphrasing of the interlocutor's directive "later, you have own. Cut your own pieces" in line 28; the subject inches forward to have a closer look at the actions of the interlocutor, probably so he could execute the action with ease. The subject could also be interested in the activity itself, hence the eagerness to complete a perlocutionary action.

\section{Results and Discussion}

The results revealed how directive speech acts affect the interaction in terms of the perlocutionary effects of the ASD child during the joint comprehension activities. It also observed the accomodating role of the interlocutor during joint-comprehension activities as well as how the conversational structure and turn-taking sequences are affected.

Directives and Perlocutions

In line with this instrumental preference, children with autism are reported to produce more feedback during interaction and comprehend better directive speech acts than speech acts that facilitate shared understanding such as representatives and expressive speech acts (BaronCohen, 1988). This phenomenon is also observed in the data as the subject reacts more according to instructions given by the interlocutor (Sparapani et al., 2020). For example, the interlocutor asked the subject to switch off the air-conditioner in Excerpt 9:

\section{Excerpt 9, Transcript 2}

Location: Subject's Home

Participants: Interlocutor (I), Subject A (A).

\begin{tabular}{|l|l|l|}
\hline 334 & A & turn off the aircond. \\
\hline 335 & I & mm, why? A? \\
\hline 336 & A & why do you want to turn off the aircond. \\
\hline 337 & I & why..is it cold? \\
\hline 338 & A & yeah! \\
\hline 339 & I & are you sure? \\
\hline 340 & A & throw away from na....negative balance \\
\hline 341 & I & okay you can go switch off the aircond \\
\hline 342 & A & (turns off the aircond) turn on! \\
\hline
\end{tabular}

Instead of prolonging the conversation in which the subject has started to provide an incoherent response "throw away from negative balance" as seen in line 340, the interlocutor then directs the subject to switch off the air-conditioner in line 341 thus eliciting a perlocutionary action by 
the subject, almost immediately. More data of the same nature are present throughout the study, and it could be possible that the subject himself wanted to elicit the actions as directed, as it would be easier to do them rather than discussing them with the interlocutor. Such findings are in tandem with the findings of Gernsbacher, Morson and Grace (2015) where directive speech acts are easily responded to by ASD children compared to speech acts that require comprehension of both speaker(ASD child) and interlocutor.

Directives imply the speaker's desire that the hearer performs an action. For example, a mother asking her child to clean up her room; "Aminah, clean up your room before going to school". In contrast to the joint-comprehension nature of the activity, directive speech acts are one-sided in a way that the subject does not need to understand why the directive is given (Wahyunianto et al., 2020), but merely just having to do them. As Searle (1979) made a distinction between direct and indirect speech acts, indirect speech acts being utterances that are understood from the context without mentioning the act itself. It is also observed that the subject is more eager to receiving a directive speech act and then performing a perlocutionary action. This act could be observed in Excerpt 10:

Excerpt 10, Transcript 2

Location: Subject's Home

Participants: Interlocutor (I), Subject (A).

\begin{tabular}{|l|l|l|}
\hline 347 & I & have you cut the borders? \\
\hline 348 & A & yeah \\
\hline 349 & I & can you show me? \\
\hline 350 & A & passing the paper) \\
\hline 351 & I & A< can you show me the borders that you've cut? \\
\hline 352 & A & shows the borders) \\
\hline
\end{tabular}

In line 350, the subject passed his work to the interlocutor and was given a follow-up directive speech act "can you show me the border that you've cut" to emphasize on the intended perlocutionary action. Instead of continuing with cutting the papers after passing the completed craft, the subject moves over closer to the interlocutor and points at the borders that he was directed to cut earlier and echoes the interlocutor with "...show the borders".

According to Searle's Speech Act Theory, speakers perform illocutionary acts to convey communicative intentions, such as requests, apologies, and promises. The subject was also observed to be working along with the interlocutor and even reaffirms his understanding of directives from the interlocutor before performing a perlocutionary action (Except 11):

Excerpt 11, Transcript 2

Location: Subject's Home

Participants: Interlocutor (I), Subject (A).

31 I A look closely you will have to do this on your own later

32 A later, you have own. Cut your own pieces 
Vol. 10, No. 1, 2021, E-ISSN: 2226-6348 @ 2021 HRMARS

33 I yes,

34 A $\quad$...(looks closer)

After reaffirming his understanding of the directive through paraphrasing of the interlocutor's directive "later, you have own. Cut your own pieces" as seen in line 32; the subject inches forward to have a closer look at the actions of the interlocutor, probably so he could execute the action with ease. The subject could also be interested in the activity itself, hence the eagerness to complete a perlocutionary action. Excerpt 12 showcases a similar example but during a different activity:

Excerpt 12, Transcript 2

Location: Subject's Home

Participants: Interlocutor (I), Subject (A).

\begin{tabular}{|l|l|l|}
\hline 369 & I & $\begin{array}{l}\text { do you wanna take a break from cutting, do you wanna read for a } \\
\text { while? }\end{array}$ \\
\hline 370 & A & yeah...but for 5 minutes okay \\
\hline 371 & I & alright..yeah, so sit properly \\
\hline 372 & A &.. (moves from chair) \\
\hline 373 & I & no no you can rest while sitting \\
\hline 374 & A & yes! (starts reading) \\
\hline 375 & I & okay, read loudly A so I can hear \\
\hline 376 & A & $\begin{array}{l}\text { TODAY IVE BEEN TIDY TO HELP OUT AT HOME, I SHORTEN MY } \\
\text { CRAYONS< THAT WAS TIDY... (continues) }\end{array}$ \\
\hline
\end{tabular}

Searle (1979) also argues that in order to understand indirect speech acts, the speaker and hearer need to have mutually shared factual background information, and the ability of the hearer to make inferences which as explained earlier, is harder to apply to interactions with children with ASD due to the pragmatic deficit that is present within them. This can be observed in the turn that the interlocutor provides an indirect speech act, "no no you can rest while sitting" in line 373 when the subject decides to lie down and read a book. The interlocutor tells the subject that he could rest and read by just sitting where he was, but the subject's understanding of the matter was that he would lie down to rest. Hence, the straightforward response by the subject by reading loudly upon the utilization of a directive speech act "okay, read loudly so I can hear" as seen in line 375 .

\section{Conversational Structure}

A conversation has its dynamic structure and rules, and it is organized in sequence in order to make the conversation meaningful, enjoyable and understandable (Sacks, Schegloff and Jefferson, 1978). It is a time during which a single participant speaks, within a typical, orderly arrangement in which participants speak with minimal overlap and gap between them. The speaker should know when he should stop and when he should speak now or later. An obvious observation is that conversation is characterized by turn-taking: participant A, talks and stops, and participant B starts, talks, stops, and henceforth to obtain A-B-A-B distribution of talk across 
two participants. In the case of this study, the conversational structure is centred between the subject and the interlocutor. Also, as observed in the previous section, speech acts do indeed have an impact on the conversational structure, especially directive speech acts. This is attested by Wahyunianto et al. (2020) where they stated that most of the children with autism were using a directive speech act. Excerpt 13 shows an instance during the joint-comprehension activity where the interlocutor utilized an expressive speech act "no? Is it easy?" as observed in line 83 in order to gauge the subject's understanding:

\section{Excerpt 13, Transcript 2}

Location: Subject's Home

Participants: Interlocutor (I), Subject (A).

\begin{tabular}{|l|l|l|}
\hline 79 & I & okay no you can continue cutting. \\
\hline 80 & A & (continues cutting) \\
\hline 81 & I & is it hard? \\
\hline 82 & A & \multicolumn{1}{|c|}{-No } \\
\hline 83 & I & no? is it easy? \\
\hline 84 & A & (looks at I) \\
\hline 85 & I & is it easy to cut it? \\
\hline 86 & A & be careful don't red your fingers \\
\hline 87 & I & yeah \\
\hline
\end{tabular}

The subject was observed to skip his turn and gazed at the interlocutor, signalling his lack of comprehension or a pragmatic deficit from the question. While this is commonplace as established prior, the conversational structure was affected where it no longer goes in an A-B-A$B$ pattern as the turn by the subject was omitted. This phenomena could also be observed in Excerpt 14 below where the interlocutor uses another indirect speech act "so what should you do now?" in line 209 instead of providing a directive speech act; 
Vol. 10, No. 1, 2021, E-ISSN: 2226-6348 @ 2021 HRMARS

\section{Excerpt 14, Transcript 2}

Location: Subject's Home

Participants: Interlocutor (I), Subject (A).

\begin{tabular}{|l|l|l|}
\hline 207 & I & $\begin{array}{l}\text { okay next, I would like you to do the same thing like you did earlier, } \\
\text { with this paper (shows paper) }\end{array}$ \\
\hline 208 & A & ...(takes paper) \\
\hline 209 & I & so what should you do now? \\
\hline 210 & A & $\ldots .$. \\
\hline 211 & I & A? what should you do now? Can you tell me? \\
\hline 212 & A & $\ldots$ \\
\hline 213 & I & A? \\
\hline 214 & A & take a new... \\
\hline 215 & I & $\begin{array}{l}\text { okay now what should you do? A..look at me. So, what should you } \\
\text { do now? }\end{array}$ \\
\hline 216 & A & shaving! (reads paper) \\
\hline 217 & I & $\begin{array}{l}\text { not shaving, I want you to cut the borders, accordingly, like you did } \\
\text { just earlier. Can you do that? }\end{array}$ \\
\hline 218 & A & .... \\
\hline 219 & I & do you want me to show you? \\
\hline 220 & A & yeah.. \\
\end{tabular}

Despite the subject's ability to complete the activity prior, now he seems not to know what to answer when questioned. The subject had skipped his turn three times throughout the excerpt when being asked what should be done as seen in lines 209, 211, and 213. The change from directives to asking questions has resulted in the subject facing pragmatic deficit as he is not able to mind-read due to the lack of Theory of Mind (Baron-Cohen, 1985), as established in the literature review The conversational structure has been disturbed as the turns are not balanced, hence resulting in a constrained interaction.

Similar to the previous excerpt, Excerpt 15 also shows how the conversational structure was affected when the interlocutor uses questioning act "so you should open the door? Is it that?" in line 215 during an interaction: 


\section{DEVELOPMENT}

Vol. 10, No. 1, 2021, E-ISSN: 2226-6348 @ 2021 HRMARS

Excerpt 15, Transcript 2

Location: Subject's Home

Participants: Interlocutor (I), Subject (A).

\begin{tabular}{|l|l|l|}
\hline 210 & A & open, open the door \\
\hline 211 & I & why? \\
\hline 212 & A & for the...cat \\
\hline 213 & I & because the cat is knocking on the door? \\
\hline 214 & A & nooo \\
\hline 215 & I & so you should open the door? Is it that? Is that it? \\
\hline 216 & A & $\ldots$ \\
\hline
\end{tabular}

Speech acts are essential in maintaining a balanced conversational structure. The lack of pragmatic understanding by the subject does not support speech acts that require shared understanding (Deliens et al., 2018). Instead, speech acts that are more direct such as declaratives and especially directives are observed to assist in promoting a turn during a conversation (Wahyunianto et al., 2020).

\section{Turn-Taking sequence(s)}

The turn taking-sequences during the interactions are somewhat methodical (Wibowo et al., 2020), in a way that the subject will await prompts by the interlocutor to continue with his turn, even if it is his turn to respond. Kasher (1991) also states that the turn-taking and differentiation of new from old information are inadequate. This can be seen throughout the data, and is aptly portrayed in the excerpt below:

\section{Excerpt 4, Transcript 4}

Location: Subject's Home

Participants: Interlocutor (I), Subject (A).

\begin{tabular}{|r|l|l|}
\hline 1 & I & Hello A \\
\hline 2 & A & Hello memey \\
\hline 3 & I & Hello A \\
\hline 4 & A & Hello A \\
\hline 5 & I & why do you say A \\
\hline 6 & A & why do you say A \\
\hline 7 & I & who am i? who am i? \\
\hline 8 & A & AMSA, \\
\hline 9 & I & I am AMSA and you are? \\
\hline 10 & A & A \\
\hline
\end{tabular}

Line 4 and line 6 in Excerpt 4 shows the subject's repetition of the greeting by the interlocutor, where a TD (Typically Developing) child would probably greet back. Upon further prompts by the interlocutor, the subject replies in line 8 instead of repeating. The turn-taking sequences become stagnant with such feature as the subject faces a pragmatic deficit (Baron-Cohen, 2019), which 
Vol. 10, No. 1, 2021, E-ISSN: 2226-6348 @ 2021 HRMARS

in this case, the subject did not understand the intention of the interlocutor. Line 138 in Excerpt 5 shows the subject skipping his turn when asked on the action that should be taken after yawning:

Excerpt 5, Transcript 2

Location: Subject's Home

Participants: Interlocutor (I), Subject (A).

\begin{tabular}{|l|l|l|}
\hline 133 & I & what do you say? \\
\hline 134 & A & Thank you I \\
\hline 135 & I & No what do you say if you yawn? \\
\hline 136 & A & I ask. \\
\hline 137 & I & No what do you say if you yawn? \\
\hline 138 & A & $\ldots .$. \\
\hline 139 & I & you cover your mouth and then..? \\
\hline 140 & A & (covers mouth)..stop coughing okay!! \\
\hline
\end{tabular}

Only through the prompt of the interlocutor in line 139 does the subject regains his turn in the conversation. From observation and reference with his family members, it appears that the subject replies with 'stop coughing' as he was previously reminded consistently to cover his mouth when coughing. He would have probably assumed that the interlocutor's prompt in line 139 was to prompt him on his coughing etiquette

\section{Organization of sequence and repair}

Following the previous examples where the sequence of turn-taking was disturbed, the subject was shown to be somewhat mindful of his replies to the interlocutor through his organization of sequence and repair. This can be observed in the Excerpt 6:

Excerpt 6, Transcript 4

Location: Subject's Home

Participants: Interlocutor (I), Subject (A).

\begin{tabular}{|r|l|l|}
\hline 183 & I & A, what do you day if somebody says thank you? \\
\hline 184 & A & thank you \\
\hline 185 & I & no what do you say, how do you reply? \\
\hline 186 & A & thank you amsa \\
\hline 187 & I & no what do you say if I tell you thank you? \\
\hline 188 & A & thank you amsa \\
\hline 189 & I & -you said you're? \\
\hline 190 & A & you're welcome \\
\hline
\end{tabular}

After three prompts in lines 185, 187 and 189 by the interlocutor, the subject finally repaired his answer in 190, thus completing the loop of question-answer with the interlocutor. Such can be 
INTERNATIONAL JOURNAL OF ACADEMIC RESEARCH IN PROGRESSIVE EDUCATION AND

DEVELOPMENT

Vol. 10, No. 1, 2021, E-ISSN: 2226-6348 @ 2021 HRMARS

observed throughout the data, and despite the repair, it is in the same vein of Kasher's (1991) findings where the turn-taking and differentiation of new from old information are inadequate.

Another excerpt also shows the organization of repair by the subject during an interaction:

Excerpt 7, Transcript 3

Location: Subject's Home

Participants: Interlocutor (I), Subject A (A).

\begin{tabular}{|l|l|l|}
\hline 186 & I & whose porridge did goldilocks ate? \\
\hline 187 & A & he ate porridges \\
\hline 188 & I & She ate porridges \\
\hline 189 & A & she ate porridges \\
\hline
\end{tabular}

In line 189 , the subject repaired his use of pronouns from 'he' to 'she' almost immediately upon the prompt by the interlocutor. Many instances have shown that the subject is very efficient in assisted-repair. The subject was also able to repair his response without the prompt of the interlocutor, as seen in line 374 in Excerpt 8:

Excerpt 8, Transcript 4

Location: Subject's Home

Participants: Interlocutor (I), Subject (A).

\begin{tabular}{|r|l|l|}
\hline 369 & I & well yeah, the story is about a guy -about a boy whose been tidy \\
\hline 370 & A & yeah \\
\hline 371 & I & what did he do? \\
\hline 372 & A & $\ldots$ \\
\hline 373 & I & A, what did he do? \\
\hline 374 & A & do with...a I SORTED OUT MY CRAYONS \\
\hline 375 & I & he sorted his crayons, other than that \\
\hline 376 & A & -yeah! \\
\hline
\end{tabular}

The organization of turn-taking, organization of sequences and organization of repair makes up the talk-in-interaction of the subject ( $O^{\prime}$ Reilly et al., 2016; Wahyunianto et al., 2020) and are intimately affected by the directive speech acts causing a conundrum in the turn-taking sequence with the interlocutor.

The presentation above has illustrated the extent of how the use of directive speech acts by the interlocutor affects the conversational structure and turn-taking sequence between the ASD child and the interlocutor, during joint comprehension activities. Using directive speech acts in place of indirect speech acts has been shown to affect the conversational structure positively whereas using indirect speech acts or speech acts that required shared understanding causes the subject to face pragmatic deficit and thus skipping his turns. This finding is in-line with Baron-Cohen's (1988) and Gernsbacher et al. (2015) findings of the same nature where using directive speech acts allow the subject to continue his turn in interaction. 


\section{Conclusion}

This paper highlighted that the findings during interactions with an ASD child are in tandem with other studies (Baron-Cohen, 1988; Wire, 2005; Gernsbacher et al., 2015). This indicates that directive speech acts are critical in eliciting meaningful responses from Autistic children. Another significant finding is that the subject was observed to produce more feedback during interaction and comprehend better directive speech acts than speech acts that required shared understanding such as representatives and expressive speech acts. When the interlocutor used directive speech acts instead of indirect speech acts, it is observed that the usage of the former had affected the conversational structure positively whereas using the latter, or other types of speech acts like questioning that required shared understanding, had caused the subject to face pragmatic deficit and thus straining the interaction. Despite that, it is observed that indirect speech acts invites illocutionary acts to convey communicative intentions, such as requests, apologies, and promises, by the subject (Wahyunianto et al., 2020). This further explains that while directive speech acts supports continual sequencing in interaction, indirect speech act could support comprehension of the subject's intention, although this would be more difficult in practice.

Theoretically, Baron-Cohen's (Baron-Cohen et al., 1985; Baron-Cohen, 2000) study on the lack of ToM (Theory of Mind) in autistic individuals correlates with the findings of the study where it is not probable to assume that an autistic child could comprehend implicatures, and that directive speech acts are better suited in eliciting or sustaining interaction with the said autistic child/individual. This in turn correlates to the perlocutionary effect by the subject when applying Austin's (1962) Speech Acts Theory. That directive speech acts, does act as an illocution to instigate a perlocutionary action from the subject. The findings also further strengthens the Triad of Impairments (Tol) (Wing, 1981) that are exclusively found in autistic children. Tol, referring to the three core deficits found in ASD children, namely, in socialization and social interaction, language and communication, and a preference for repetitive, stereotyped behaviour rather than creative play (Faras, 2010; Hie \& Kee, 2019), are further emphasized in the extracts of conversation while the usage of certain speech acts keeps the interaction in a repetitive and stereotyped behaviour.

The turn taking-sequences during the interactions are somewhat mathematical, in a way that the subject will await prompts by the interlocutor to continue with his turn, even if it is his turn to respond (Sparapani et al., 2020). The subject understands the need for turn-taking and it can be observed in almost all of the excerpts where the subject will adhere to the rule of turn-taking, by replying after each of the interlocutor's dialog. However, the pressure of keeping the turn-taking during a conversation might have resulted in the subject providing answers/reply impulsively without any self-repair/deep thought. In retrospect, the findings of the study provide insights into the interaction/communication of a Malaysian English speaking ASD child during jointcomprehension activities in Malaysia.

Contextually, this study is limited in its applicability to larger pool of children on the spectrum whereby it is a case-study. In using a case study approach the researcher was able to focus on specific cases such as the subject of the study rather than a statistical study, and that would enable the researcher to study complex phenomena within the participant's context. The studies reviewed on the subject matter (refer to literature review) are mostly studies with bigger samples 
that look at strategies and interventions for language and cognitive development (Yeo \& Teng, 2015) where the recorded data in the class or laboratory setting were not analyzed using discourse analytic approaches. This study had focused on the perlocutionary effects elicited via the use of directive speech acts, and was analysed via discourse analytic approaches (refer to methodology). Future discourse analysis studies could provide further understanding of the phenomenon with a bigger data sample.

In retrospect, children with autism can perform several categories of speech acts effectively with directive speech acts being the most performed by the children with autism regarding its use (Wahyunianto et al., 2020). Adding on to the current literature available, directive speech acts are utilised naturally not only by TP (typically developing) children, but also by autistic children. Combined with the fact that educators (-and most people) use of directive speech acts in guiding/teaching, there are implications towards teaching language for specific purposes. Knowledge of the speech acts used by ASD children is important, as well as the communication skills training among special needs facilitators, since it could conjure meaningful interactions between ASD children and those who communicate with them. It is therefore proposed that the findings from this study be used in teachers training programs (special needs education) to raise awareness of patterns of discourse behavior during interactions with them, with a view to improving the professional experience and skills of teachers (Wibowo et al., 2020).

\section{References}

Adamson, L. B., Bakeman, R., Suma, K., \& Robins, D. L. (2019). An expanded view of joint attention: Skill, engagement, and language in typical development and autism. Child development, 90(1), e1-e18.

Allott, R. (2001). Autism and the motor theory of language. In The Great Mosaic Eye: Language and Evolution (pp. 93-113). University of Southampton: Book Guild.

American Psychiatric Association (2013). Diagnostic and statistical manual of mental disorders ( $5^{\text {th }}$ ed.). Arlington, VA: American Psychiatric Publishing.

Asperger, H. (1944). Die „Autistischen Psychopathen” im Kindesalter. European Archives of Psychiatry and Clinical Neuroscience, 117(1), 76-136.

Austin, J. L. (1962). How to do things with words. Cambridge,: Oxford University Press.

Baker, J. L., Rotimi, C. N., \& Shriner, D. (2017). Human ancestry correlates with language and reveals that race is not an objective genomic classifier. Scientific reports, 7(1), 1-10.

Baron-Cohen, S. (2000). Theory of mind and autism: A fifteen year review. Understanding other Minds: Perspectives from Developmental Cognitive Neuroscience, 2, 3-20.

Baron-Cohen, S., Leslie, A. M., \& Frith, U. (1985). Does the autistic child have a 'theory of mind'? Cognition, 21, 37-46.

Baron-Cohen, S. (1988). Social and pragmatic deficits in autism: Cognitive or affective?. Journal of Autism and Developmental Disorders, 18(3), 379-402.

Baron-Cohen, S. E., Tager-Flusberg, H. E., \& Cohen, D. J. (1994). Understanding other minds: Perspectives from autism. In Most of the chapters in this book were presented in draft form at a workshop in Seattle, Apr 1991.. Oxford University Press.

Baron-Cohen, S. (2019). Infantile autism. Companion Encyclopedia of Psychology: Volume Two (pp. 918-929) London: Routledge. 
Baxter, P., \& Jack, S. (2008). Qualitative case study methodology: Study design and implementation for novice researchers. The Qualitative Report, 13(4), 544-559.

Che An, A. G. (2010) Conversation Skills of an Autistic Teenager: A Pragmatic Analysis. (Unpublished doctoral dissertation). Universiti Malaya. Petaling Jaya. Malaysia.

Deliens, G., Papastamou, F., Ruytenbeek, N., Geelhand, P., \& Kissine, M. (2018). Selective pragmatic impairment in autism spectrum disorder: Indirect requests versus irony. Journal of Autism and Developmental Disorders, 48(9), 29382952.

Faras, H., Al Ateeqi, N., \& Tidmarsh, L. (2010). Autism spectrum disorders. Annals of Saudi medicine, 30(4), 295-300.

Frith, U., \& Happé, F. (1994). Autism: Beyond "theory of mind". Cognition, 50(1-3), 115-132.

Gernsbacher, M. A., Morson, E. M., Grace, E. J. (2015). Language Development in Autism, Neurobiology of Language, pp 879-886.

Gernsbacher, M. A., Morson, E. M., \& Grace, E. J. (2016). Language and speech in autism. Annual review of linguistics, 2, 413-425.

Goffman, E. (1961). Encounters: Two studies in the sociology of interaction. Northwestern University: Ravenio Books.

Hie, J. P. T., \& Kee, J. Y. (2019). Preschool teachers'perceptions on social communication skills of children with autism spectrum disorder. Jurnal Penyelidikan Dedikasi, 15.

Hochman, J. M., Carter, E. W., Bottema-Beutel, K., Harvey, M. N., \& Gustafson, J.R. (2015). Efficacy of peer networks to increase social connections among high school students with and without autism spectrum disorder. Exceptional Children, 82(1), 96116.

Kanner, L. (1943). Autistic disturbances of affective contact. Nervous Child, 2(3), 217-250.

Kasher, A. (1991). On the pragmatic modules: a lecture. Journal of Pragmatics, 16:381-397.

Kremer-Sadlik, T. (2005). To Be or Not to Be Bilingual: Autistic Children from Multilingual Families. Cascadilla Press, Proceedings of the $4^{\text {th }}$ International Symposium on Bilingualism, Arizona State University.

Lee, A., Hobson, R. P., \& Chiat, S. (1994). I, you, me, and autism: An experimental study. Journal of Autism and Developmental Disorders, 24(2), 155-176.

Leslie, A. M. (1987). Pretense and representation: The origins of" theory of mind.". Psychological Review, 94(4), 412.

Liao, X., Lei, X., \& Li, Y. (2019). Stigma among parents of children with autism: A literature review. Asian Journal of Psychiatry, 45, 88-94.

Filha, M. C. (2013). A study in contrastive analysis and error analysis: article usage in english and portuguese.. Departamento de Língua e Literatura Estrangeiras: Universidade Federal De Santa Catarina.

May, C. (2016). How parents, teachers and doctors can really help with autistic children. Star2.com, Retrieved from https://www.star2.com/family/children/2016/04/18/howparents-teachers-and-doctors-can-really-help-autistic-children/

Nair, R. S., (2015). Challenges, strategies and Success Gained by a Teacher in Teaching Autism Students in a Private Centre. International Journal of Social Science and Humanities Research, Vol. 3, Issue 2, 419-425. 
INTERNATIONAL JOURNAL OF ACADEMIC RESEARCH IN PROGRESSIVE EDUCATION AND

DEVELOPMENT

Vol. 10, No. 1, 2021, E-ISSN: 2226-6348 @ 2021 HRMARS

Newschaffer, C. J., Croen, L. A., Daniels, J., Giarelli, E., Grether, J. K., Levy, S. E., ...\& Reynolds, A. M. (2007). The epidemiology of autism spectrum disorders. Annu. Rev. Public Health, 28, 235-258.

O'reilly, M., \& Parker, N. (2013). 'Unsatisfactory Saturation': a critical exploration of the notion of saturated sample sizes in qualitative research. Qualitative Research, 13(2), 190-197.

O'Reilly, M., Lester, J. N., \& Muskett, T. (2016). Discourse/Conversation Analysis and Autism Spectrum Disorder. Journal of Autism and Developmental Disorders, 46(2), 355-359.

Parsons, L., Cordier, R., Munro, N., \& Joosten, A. (2019). The feasibility and appropriateness of a peer-to-peer, play-based intervention for improving pragmatic language in children with autism spectrum disorder. International Journal of SpeechLanguage Pathology, 21(4), 412-424.

Potter, J. (2012). Discourse analysis and discursive psychology. Qualitative Research in Psychology (pp. 73-94). Washington: American Psychological Association Press.

Sacks, H., Schegloff, E. A., \& Jefferson, G. (1978). A simplest systematics for the organization of turn taking for conversation. In Studies in the organization of conversational interaction (pp. 7-55). New York: Academic Press.

Sacks, H. (1992). Lectures on Conversation (edited by G. Jefferson). Malden, MA: Blackwell Publishing.

Searle, J. R. (1975). A taxonomy of illocutionary acts. Language Mind, and Knowledge (pp. 344369). Minneapolis, University of Minnesota Press.

Searle, J. R. (1979). Expression and meaning : Studies in the theory of speech acts. Cambridge, Eng. ; New York: Cambridge University Press.

Searle, J. R. (1985). Expression and meaning: Studies in the theory of speech acts. New York: Cambridge University Press.

Searle, J. R. (1986). Meaning, communication, and representation. Philosophical grounds of rationality: Intentions, Categories, Ends (pp. 209-226). Oxford University Press.

Shire, S. Y., Shih, W., Bracaglia, S., Kodjoe, M., \& Kasari, C. (2020). Peer engagement in toddlers with autism: Community implementation of dyadic and individual Joint Attention, Symbolic Play, Engagement, and Regulation intervention. Autism, 1362361320935689.

Sparapani, N., Solari, E., Towers, L., McIntyre, N., Henry, A., \& Zajic, M. (2020). Secondary Analysis of Reading-Based Activities Utilizing a Scripted Language Approach: Evaluating Interactions Between Students With Autism and Their Interventionists. Journal of Speech, Language, and Hearing Research, 1-23.

Sterponi, L., \& Shankey, J. (2014). Rethinking echolalia: Repetition as interactional resource in the communication of a child with autism. Journal of Child Language, 41(2), 275-304.

Sterponi, L., \& de Kirby, K. (2016). A multidimensional reappraisal of language in autism: Insights from a discourse analytic study. Journal of Autism and Developmental

Disorders, 46(2), 394-405.

Tager-Flusberg, H. (1985). The conceptual basis for referential word meaning in children with autism. Child Development, 1167-1178.

Tager-Flusberg, H. (2000). Understanding the language and communicative impairments in autism. In International review of research in mental retardation (Vol. 23, pp. 185205). Academic Press. 
Tager-Flusberg, H. (2007). Evaluating the theory-of-mind hypothesis of autism. Current Directions in Psychological Science, 16(6), 311-315.

Thomas, D. R. (2006). A general inductive approach for analyzing qualitative evaluation data. American Journal of Evaluation, 27(2), 237-246.

Wahyunianto, D., \& Purnanto, D. (2020, March). The Use of Speech Act as Communication Strategy of Children with Autism. In 3rd International Conference on Language, Literature, Culture, and Education (ICOLLITE 2019) (pp. 324-328). Atlantis Press.

Watkins, L., O’Reilly, M., Kuhn, M., Gevarter, C., Lancioni, G. E., Sigafoos, J., \&Lang, R. (2015). A review of peer-mediated social interaction interventions for students with autism in inclusive settings. Journal of Autism and Developmental Disorders, 45(4), 1070-1083.

Wibowo, A. H., Halim, H., \& Mohamad, B. (2020). Multimodal Strategies in Teaching Children with Autism: A Discourse Analysis. Systematic Reviews in Pharmacy, 11(2).

Wing, L. (1981). Language, social, and cognitive impairments in autism and severe mental retardation. Journal of autism and developmental disorders, 11(1), 31- 44.

Wing, L. (1981). Asperger's syndrome: a clinical account. Psychological Medicine, 11(1), 115-129.

Wire, V. (2005). Autistic spectrum disorders and learning foreign languages. Support for Learning, 20(3), 123-128.

Yamat, H., Fisher, R., \& Rich, S. (2014). Revisiting English language learning among Malaysian children. Asian Social Science, 10(3), 174-180. doi:10.5539/ass.v10n3p174

Yeo, K. J., \& Teng, K. Y. (2015). Social Skills Deficits in Autism: A Study among Students with Austim Spectrum Disorder in Inclusive Classrooms. Universal Journal of Educational Research, 3(12), 1001-1007. 